${ }^{1}$ School of Health Sciences, Positivo University - UP, Curitiba, Paraná, Brazil.

${ }^{2}$ Department of Dentistry, University of Joinville Region - Univille, Joinville, Santa Catarina, Brazil.

${ }^{3}$ Department of Dentistry, Tuiuti University of Paraná - UTP, Curitiba, Paraná, Brazil.
*Corresponding author: Flares Baratto-Filho 10 Paulo Malschitzki, Zona Industrial Norte, Joinville, Santa Catarina, 89219-710, Brazil. Phone: +55 41991042685 E-mail: fbaratto1@gmail.com

Editor: Dr Altair A. Del Bel Cury

Received for publication: December 30, 2020

Accepted: March 29, 2021

\section{Influence of different reciprocating systems on the apical extrusion of debris in flat-oval canals}

\author{
Monique Marchiori ${ }^{1}$ iD, Arissa Michelle Yamada \\ Corrêa $^{2}$ (iD, Flávia Sens Fagundes Tomazinho ${ }^{1}$ (iD), \\ Marilisa Carneiro Leão Gabardo ${ }^{1}$ iD, Natanael \\ Henrique Ribeiro Mattos ${ }^{3}$ (ID), Luiz Fernando \\ Fariniuk $^{3}$ (iD), Flares Baratto-Filho ${ }^{2,3,{ }^{*}}$ (iD
}

Aim: To evaluate the apical extrusion of debris in flat-oval canals, using three reciprocating systems at two different working lengths $(\mathrm{WL}), 0 \mathrm{~mm}$ and $1 \mathrm{~mm}$ from the apical foramen. Methods: Ninety mandibular incisors were randomly divided into three groups based on the systems: WaveOne Gold \#25.07 (WOG), ProDesign R \#25.06 (PDR), and X1 Blue \#25.06 (X1B). Extruded debris were collected and dried in pre-weighed Eppendorf tubes. Three consecutive weighings were performed for each tube, and the mean was calculated. If the assumptions of normality and homogeneity of variance were not met, the Kruskal-Wallis test was used to analyze the amount of extruded debris between groups with the same WL, and the Mann-Whitney $U$ test was used for comparison within groups for each WL. Results: All groups had extruded debris, with higher median values occurring at $1 \mathrm{~mm}$. No significant difference regarding the amount of debris extrusion was observed at $0 \mathrm{~mm}(p>0.05)$ and $1 \mathrm{~mm}(p>0.05)$ between groups. However, within the groups, at different $\mathrm{WL}$, there was greater extrusion at $1 \mathrm{~mm}(\mathrm{p}<0.05)$, with PDR differing significantly from the other systems $(p<0.05)$. Conclusion: The extrusion of debris occurred regardless of the group, with higher values at $1 \mathrm{~mm}$. However, using PDR at $1 \mathrm{~mm}$ from the apical foramen showed the highest values of extrusion.

Keywords: Dental pulp cavity. Root canal preparation. Tooth apex. 


\section{Introduction}

Root canal preparation is an essential step of endodontic treatment that includes the cleaning, shaping, and disinfection of root canals ${ }^{1}$. The irrigation procedure assists in the lubrication of the root canal walls, favoring the cutting action of endodontic instruments and the removal of tissue remnants, such as pulp and dentin?

The quality of root canal preparation depends on the design, kinematics, and cutting ability of instruments. In this context, the nickel-titanium (NiTi) alloy increases the flexibility and cyclic fatigue strength of instruments, making them resistant to torsional failure ${ }^{2,3}$. Reciprocating systems with this alloy allow faster and more efficient preparation of the root canal with a single instrument ${ }^{4}$.

WaveOne Gold (WOG) (Dentsply Sirona, Ballaigues, Switzerland) is a reciprocating system represented by a parallelogram cross-section with a variable taper. This system is manufactured with NiTi gold alloy technology that increases flexibility, providing better resistance to cyclic fatigue ${ }^{3,4}$. The ProDesign R (PDR) instrument (Easy Equipamentos Odontológicos, Belo Horizonte, Brazil) is a reciprocating system with an S-shaped cross-section. It is produced with NiTi CM control memory alloy, making it extremely flexible, but without shape memory,6. The X1-Blue (X1B) File (MK Life, Porto Alegre, Brazil) features single-use reciprocating kinematics with a triangular cross-section and is manufactured with blue heat treatment technology ${ }^{7}$. Thermomechanically treated NiTi alloys have been reported to be more flexible with improved cyclic fatigue resistance and greater angle of deflection at failure than conventional NiTi alloy ${ }^{8}$.

The design of reciprocating instruments is such that debris removal is in the coronary direction and its apical extrusion is decreased ${ }^{7,9}$. Debris can be released in the periapical region during root canal preparation, causing damage to peri-radicular structures and delayed healing ${ }^{10,11}$, with probable causes related to root canal anatomy, instrument design, and technique ${ }^{9,10}$. Several studies have aimed to evaluate this extrusion ${ }^{9-18}$, including analysis with flat-oval canals ${ }^{13,18}$, and regardless of the instrumentation used, extrusion does occur ${ }^{10,13}$.

Another relevant issue concerning the preparation is the working length $(W L)$ determination, which must be adjusted in the apical constriction associated with the main foramen, thereby allowing a better mechanical debridement of the apical area, better irrigation, disinfection, and reduction of the amount of extruded debris 9 .

To date, no endodontic instrument/system has completely eliminated the possibility of apical extrusion of debris. This study aimed to evaluate this occurrence with the reciprocating instruments WOG, PDR, and X1B at two different WL. The null hypothesis tested was that there are no differences between the amount of debris extruded by the different instruments used, even when comparing the two WL, $0 \mathrm{~mm}$ and $1 \mathrm{~mm}$.

\section{Material and Methods}

\section{Sample selection}

The local research ethics committee approved the research project ( $n^{\circ} 2.716 .775$ ). A priori sample calculation was not performed. However, for the variable debris weight 
(mg), which was different at different WL (mm) using the Mann-Whitney non-parametric test, the debris weight rank (mg) and the test power was calculated, which was $70 \%$. Thus, 90 recently extracted mandibular central incisors were selected, cleaned, and stored in distilled water. The inclusion criteria were single root canal, complete rhizogenesis, at least $19 \mathrm{~mm}$ of length, canal with single foramen and patency, absence of internal/external root resorption, no root fractures, and no previous endodontic treatment. Digital radiographs in the mesiodistal and buccolingual directions were taken to select the flat-oval canals (buccolingual diameter four times greater than mesiodistal diameter). To standardize the dental groups and each system, the classification by Wu et al. ${ }^{18}$ was chosen for selecting the flat-oval canals.

\section{Sample preparation}

The specimens ( $n=90$ ) were individually stored and distributed randomly into two experimental groups $(n=45)$ with different $W L: 0 ~ m m$ and $1 \mathrm{~mm}$ of the apical foramen. Subsequently, the teeth crowns were removed with 3080 diamond bur (KG Sorensen, São Paulo, Brazil), and the lengths were standardized to $19 \mathrm{~mm}$, measured using a digital pachymeter (MTX 316119, Guarulhos, Brazil). The foramen patency was then determined with a size $10 \mathrm{~K}$-file (Dentsply Sirona, Ballaigues, Switzerland) till its tip was visible, and the WL was established according to the pre-established groups.

\section{Evaluation of apical extrusion of debris}

For debris evaluation, the experimental model adapted from Myers and Montgomery ${ }^{19}$ was used. An orifice was created in the cap of an Eppendorf tube, and a specimen was inserted until the cement-enamel junction remained 1-2 $\mathrm{mm}$ above, fixed with a cyanoacrylate-based glue (IC-GEL Ethyl Cyanoacrylate Gel, Insta-Cure- BSI, Odeme Dental Research, Luzerna, Brazil). A 27-G needle was placed beside the root to balance the air pressure inside and outside the tube. Thus, the specimen was fixed in the Eppendorf tube to collect the debris extruded from the foramen. After root canal preparation, the tube was placed in an oven for evaporation. An aluminum foil covered the tube, thus blinding the operator to the root apex and process.

\section{Eppendorf tube pre-weighing}

The tubes were weighed (in $\mathrm{mg}$ ) three times using a precision analytical balance (M214Ai, Bel Engineering, Piracicaba, Brazil) with an accuracy of $10^{-4} \mathrm{mg}$, and the mean value of each weighing was obtained.

\section{Root canal preparation}

A single operator, a specialist in endodontics with five years of experience, performed all stages of the experiment. Irrigation was carried out with a total of $5 \mathrm{~mL}$ distilled water (SSPlus do Brasil Ltda, Maringá, Brazil) using a 27-G gauge needle (Endo-Eze Irrigator Tip - Ultradent, Salt Lake City, USA) with a plastic syringe (BD Plastipak $10 \mathrm{~mL}$ $\mathrm{BD}$, Curitiba, Brazil), with its tip, inserted in the WL at $3 \mathrm{~mm}^{20}$.

The instruments were driven with the X-Smart Plus motor (Dentsply Sirona, Ballaigues, Switzerland) using the "Wave One" settings. After three pecking motions, the instrument was removed from the root canal, cleaned, and inspected before being 
reused. The canal was irrigated with $1 \mathrm{~mL}$ distilled water, and a size $10 \mathrm{~K}$-file was used to check the patency. The selected group $(0 \mathrm{~mm}$ or $1 \mathrm{~mm}$ ) repeated this procedure till the instrument reached the pre-established WL. At the end of the root canal preparation, the specimens were submitted to a final irrigation with $1 \mathrm{~mL}$ distilled water with the irrigation needle positioned at $2 \mathrm{~mm}$ from the WL of each group. The same instrument was used to prepare three specimens and was then discarded.

\section{Extruded debris quantification}

After complete instrumentation, the cap, cannula, teeth, and aluminum foil were separated from the Eppendorf tube. The tubes with debris were then stored in an incubator (Incubator INC.410, New Ethics and Scientific Equipment Products Ltd., São Paulo, Brazil) at $37^{\circ} \mathrm{C}$ for seven days for the evaporation of distilled water. After this period, the tubes were weighed using the same precision analytical balance described above to quantify only extruded debris. The mean was calculated after weighing each tube three times, in which the final weight was subtracted from the initial weight.

\section{Statistical analysis}

Statistical analysis was performed using the software SPSS v. 25 (IBM SPSS Inc., Armonk, USA). The Shapiro-Wilk and Levene tests were used to verify the normality and homogeneity of data, respectively. To analyze the amount of debris extrusion between groups with the same WL, a non-parametric test (Kruskal-Wallis test) was used. The Mann-Whiney $U$ test was used to analyze this amount within the same group, considering the two WL. The level of significance was set at $5 \%$.

\section{Results}

The data obtained are shown in Table 1. Regardless of the instrument used, higher median values of extrusion were observed at $1 \mathrm{~mm}$. Regarding the $\mathrm{WL}$, no significant difference in the amount of debris extrusion was observed at $0 \mathrm{~mm}(p>0.05)$ and $1 \mathrm{~mm}(p>0.05)$ between the instruments. In contrast, taking into consideration the $\mathrm{WL}$, there was a difference in the amount of extruded debris at $1 \mathrm{~mm}(p<0.05)$, with PDR differing significantly from the others $(p<0.05)$.

Table 1. Median (minimum-maximum) of extruded debris (mg) after root canal preparation

\begin{tabular}{lcccc}
\hline $\begin{array}{l}\text { Working } \\
\text { Length }\end{array}$ & & Group & & $\begin{array}{c}\text { Median (min.-max.) } \\
\text { of debris weights } \\
\text { regardless of } \\
\text { instrument }\end{array}$ \\
\hline WOG & 0.0023 & PDR & X1B & \\
\hline mm & $(0.0000-0.0300)^{\mathrm{aA}}$ & $(0.0010-0.0200)^{\mathrm{aA}}$ & $(0.0007-0.0123)^{\mathrm{aA}}$ & $(0.0000-0.0300)^{\mathrm{A}}$ \\
\hline $1 \mathrm{~mm}$ & $\begin{array}{c}0.0037 \\
(0.0020-0.0063)^{\mathrm{aA}}\end{array}$ & $(0.0020-0.0090)^{\mathrm{aB}}$ & $(0.0003-0.0553)^{\mathrm{aA}}$ & $(0.0003-0.0553)^{\mathrm{B}}$ \\
\hline
\end{tabular}

Note: Lower case letters indicate a significant statistical difference between the groups of instruments in each WL (Kruskal-Wallis test, $\mathrm{p}<0.05$ ). Capital case letters indicate a significant statistical difference between each group of instrument in different WL (Mann-Whitney $U$ test, $p<0.05)$. 


\section{Discussion}

This study was conducted to analyze the amount of apical debris extrusion in mandibular incisors with flat-oval-shaped root canals, using reciprocating kinematics at two different WL.

The reciprocating systems WOG, PDR, and X1B were chosen because they have the same kinematics but with different tapers, cross-sections, and heat treatments. In the present study, the null hypothesis was rejected since significant differences were found in the analysis of debris extrusion when comparing the instruments and $\mathrm{WL}$, where higher values of extrusion were observed at $1 \mathrm{~mm}$.

All instruments used in this study had the same kinematics. The literature comparing manual, rotary, and reciprocating instruments has shown that greater apical extrusion of debris was obtained with manual instruments ${ }^{12,15,19}$.

The study and development of new instrument designs and different NiTi alloys with various heat treatments allow an efficient, faster and safer root canal preparation associated with the reciprocating movement ${ }^{21}$. According to Varela-Patiño et al. ${ }^{22}$, the reciprocating kinematics relieves tension in the instrument due to special counter-clockwise (cutting action) and clockwise (instrument release) movements, providing a balanced force technique that causes less extrusion of debris. Dincer et al. ${ }^{14}$ compared the reciprocating, rotary, and adaptive kinematics and showed the lowest apical extrusion values for the reciprocating and Twisted File Adaptive (TFA) system. Boijink et al. ${ }^{15}$, analyzing the WOG, TFA (SybronEndo, Orange, USA), and manual instruments, observed that reciprocating instruments extruded the least amount of debris in curved root canals. In a comparison between single-file systems, WOG and Reciproc (VDW GmbH, Munich, Germany), authors found no significant statistical difference in the amount of the debris extruded ${ }^{12}$.

Using a similar dental group as that of this study (flat-oval root canals), Kirchhoff et al. ${ }^{13}$ evaluated the amount of apically extruded debris with four different instrumentation systems: ProTaper Next (PTN; Dentsply Tulsa Dental, Tulsa, USA), WOG, TFA, and Self-Adjusting File (SAF) (ReDent-Nova, Ra'anana, Israel). The authors revealed fewer values with PTN, WOG, and TFA than SAF. However, Farmakis et al. ${ }^{16}$, in an ex vivo study with mandibular premolars with oval-shaped canals showed that WOG had a higher mean mass of apically extruded debris compared to SAF, with a significant difference.

Frota et al. ${ }^{9}$, using manual and reciprocating systems such as Reciproc, WOG and PDR found lower extrusion results with PDR, different from the results obtained in the present study in which the highest debris extrusion value was found for the PDR group. This can be possibly explained by the S-shaped cross-sectional characteristic of the PDR, which provides a greater cutting ability of the root canal walls ${ }^{5}$, when compared to the design of the cross-section of the WOG, a parallelogram with only one cutting edge in contact with the canal wall, and X1B which presents a convex triangular cross section.

Regarding the diameter of the instruments, Bürklein et al. ${ }^{23}$ and Tinaz et al. ${ }^{24}$ confirmed that the larger the diameter of the instrument's tip, the greater the apical patency, and consequently the amount of extruded debris. The differences in diameters between the instruments, that 
could be an interference factor in the results, were excluded in this study since a diameter size 25 was used. Even though the same diameter with different tapers .06 and .07 was used in this study, the results showed no significant differences due to diameter variability.

Concerning the $\mathrm{WL}$, the present results showed greater extrusion of debris at $1 \mathrm{~mm}$ of the apical foramen than at the limit of the apical foramen $(0 \mathrm{~mm})$, with a statistically significant difference. This may have occurred because the final patency made with a size $10 \mathrm{~K}$-file may have pushed these debris toward the apex instead of being moved in the coronal direction. The apical plug is formed when the instrument works - in1 $\mathrm{mm}$ at the apical foramen - with an over instrumentation of the root canal compacting the debris near the apex ${ }^{19}$. Confirming this possibility, other studies have observed that during endodontic treatment, the movements of the K-file instruments toward the apex resemble that of a piston, with push and pull kinematics, and together with irrigation can cause greater debris compaction, tissue remnants, dentin scrapings, and irrigants in periapical tissues with a blockage of the apical foramen ${ }^{24,25}$.

In a recent study to evaluate the extrusion of debris associated with the use of the Reciproc and WOG in curved canals instrumented up to different WL (at the apical foramen and $1 \mathrm{~mm}$ short of the foramen). The authors concluded that regardless of the $\mathrm{WL}$, both reciprocating systems were associated with similar results ${ }^{26}$.

Another factor that may be correlated with the results of this study is the diameter of the irrigation needle and the depth at which it is positioned during the final irrigation process. This may have influenced the higher debris extrusion values at $1 \mathrm{~mm}$ of the apical foramen. The irrigation needle used in this study was $27-\mathrm{G}$, and the irrigation length during the root canal preparation was pre-established at $2 \mathrm{~mm}$ below the $\mathrm{WL}$ of each group, which corroborates the methodology described in the studies of Uzunoglu-Özyürek et al. ${ }^{26}$ and Boutsioukis et al. ${ }^{20}$. In these studies, it was established that the needle should be positioned 2-3 $\mathrm{mm}$ at the $\mathrm{WL}$, and the space available around and below the needle is necessary for the irrigating solution to have a reverse flow towards the apex. Based on these results, it was suggested that needles with a diameter below the apical diameter of the root canal after preparation, positioned at $3 \mathrm{~mm}$ of the $\mathrm{WL}$, could improve the penetration of the apical third preventing the extrusion of debris.

To avoid the influence of different irrigating solutions, distilled water instead of sodium hypochlorite $(\mathrm{NaOCl})$ was chosen as observed in several studies ${ }^{11,16,23} . \mathrm{NaOCl}$, when subjected to high temperatures and consequent evaporation, results in the formation of crystals that mix with the debris, interfering with the results of the quantification of extruded debris ${ }^{27}$. Thus, the amount of irrigation is directly associated with greater cleaning of the root canals.

It is important to emphasize that this study used extracted teeth, and there are some limitations since the presence of periapical tissues around the foramen, in vivo, can avoid the extrusion of debris and irrigating solutions through the apical foramen ${ }^{17}$.

In this study, mandibular incisors with flat-oval canals were used, in which it may be difficult to remove all intracanal residues properly ${ }^{13,18}$. Therefore, new instruments have been developed and tested that contemplate the difficulties in cleaning and shaping root canals. Additional studies are needed in the face of these challenges to compare the results found. 


\section{In conclusion, extrusion of debris occurred regardless of the reciprocating system, with higher values at $1 \mathrm{~mm}$. However, the highest extrusion values were recorded when using PDR at $1 \mathrm{~mm}$ from the apical foramen.}

\section{References}

1. Schilder H. Cleaning and shaping the root canal. Dent Clin North Am. 1974 Apr;18(2):269-96.

2. Ounsi HF, Nassif W, Grandini S, Salameh Z, Neelakantan P, Anil S. Evolution of nickel-titanium alloys in endodontics. J Contemp Dent Pract. 2017 Nov;18(11):1090-6. doi: 10.5005/ jp-journals-10024-2181.

3. Klymus ME, Alcalde MP, Vivan RR, Só MVR, de Vasconselos BC, Duarte MAH. Effect of temperature on the cyclic fatigue resistance of thermally treated reciprocating instrument. Clin Oral Investig. 2019 Jul;23(7):3047-52. doi: 10.1007/s00784-018-2718-1.

4. Ferreira F, Adeodato C, Barbosa I, Aboud L, Scelza P, Zaccaro Scelza M. Movement kinematics and cyclic fatigue of NiTi rotary instruments: a systematic review. Int Endod J. 2017 Feb;50(2):143-52. doi: 10.1111/iej.12613.

5. De Menezes SEAC, Batista SM, Lira JOP, de Melo Monteiro GQ. Cyclic fatigue resistance of WaveOne Gold, ProDesign R and ProDesign Logic files in curved canals in vitro. Iran Endod J. 2017 Fall;12(4):468-73. doi: 10.22037/iej.v12i4.17494

6. Gavini G, Santos M, Caldeira CL, Machado MEL, Freire LG, Iglecias EF, et al. Nickel-titanium instruments in endodontics: a concise review of the state of the art. Braz Oral Res. 2018 Oct;32(suppl 1):e67. doi: 10.1590/1807-3107bor-2018.vol32.0067

7. Elashiry MM, Saber SE, Elashry SH. Apical extrusion of debris after canal shaping with three singlefile systems. Niger J Clin Pract. 2020 Jan;23(1):79-83. doi: 10.4103/njcp.njcp_319_19.

8. Zupanc J, Vahdat-Pajouh N, Schäfer E. New thermomechanically treated NiTi alloys - a review. Int Endod J. 2018 Oct;51(10):1088-103. doi: 10.1111/iej.12924.

9. Frota MMA, Bernardes RA, Vivan RR, Vivacqua-Gomes N, Duarte MAH, Vasconcelos $\mathrm{BC}$. Debris extrusion and foraminal deformation produced by reciprocating instruments made of thermally treated NiTi wires. J Appl Oral Sci. 2018 Jan;26:e20170215. doi: 10.1590/1678-7757-2017-0215.

10. Caviedes-Bucheli J, Castellanos F, Vasquez N, Ulate E, Munoz HR. The influence of two reciprocating single-file and two rotary-file systems on the apical extrusion of debris and its biological relationship with symptomatic apical periodontitis. A systematic review and meta-analysis. Int Endod J. 2016 Mar;49(3):255-70. doi: 10.1111/iej.12452.

11. Arruda-Vasconcelos R, Barbosa-Ribeiro M, Louzada LM, Mantovani GD, Gomes BP. Apically extruded debris using passive ultrasonic irrigation associated with different root canal irrigants. Braz Dent J. 2019 Jul;30(4):363-367. doi: 10.1590/0103-6440201902674.

12. De-Deus G, Neves A, Silva EJ, Mendonça TA, Lourenço C, Calixto C, et al. Apically extruded dentin debris by reciprocating single-file and multi-file rotary system. Clin Oral Investig. 2015 Mar;19(2):357-61. doi: 10.1007/s00784-014-1267-5.

13. Kirchhoff Al, Fariniuk LF, Mello I. Apical extrusion of debris in flat-oval root canals after using different instrumentation systems. J Endod. 2015 Feb;41(2):237-41. doi: 10.1016/j.joen.2014.09.023.

14. Dincer AN, Guneser MB, Arslan D. Apical extrusion of debris during root canal preparation using a novel nickel-titanium file system: WaveOne gold. J Conserv Dent. 2017 Sep-Oct;20(5):322-325. doi: 10.4103/JCD.JCD_407_16. 
15. Boijink D, Costa DD, Hoppe CB, Kopper PMP, Grecca FS. Apically extruded debris in curved root canals using the WaveOne Gold reciprocating and twisted file adaptive systems. J Endod. 2018 Aug;44(8):1289-92. doi: 10.1016/j.joen.2018.04.011.

16. Farmakis ET, Sotiropoulos GG, Abràmovitz I, Solomonov M. Apical debris extrusion associated with oval shaped canals: a comparative study of WaveOne vs Self-Adjusting File. Clin Oral Investig. 2016 Nov;20(8):2131-8. doi: 10.1007/s00784-016-1709-3.

17. Uslu G, Özyürek T, Yılmaz K, Gündoğar M, Plotino G. Apically extruded debris during root canal instrumentation with Reciproc Blue, HyFlex EDM, and XP-endo Shaper Nickel-titanium files. J Endod. 2018 May;44(5):856-9. doi: 10.1016/j.joen.2018.01.018.

18. Wu MK, R'oris A, Barkis D, Wesselink PR. Prevalence and extent of long oval canals in the apical third. Oral Surg Oral Med Oral Pathol Oral Radiol Endod. 2000 Jun;89(6):739-43. doi: 10.1067/ moe.2000.106344.

19. Myers GL, Montgomery S. A comparison of weights of debris extruded apically by conventional filing and Canal Master techniques. J Endod. 1991 Jun;17(6):275-9. doi: 10.1016/S0099-2399(06)81866-2.

20. Boutsioukis C, Lambrianidis T, Verhaagen B, Versluis M, Kastrinakis E, Wesselink PR, et al. The effect of needle-insertion depth on the irrigant flow in the root canal: evaluation using an unsteady computational fluid dynamics model. J Endod. 2010 Oct;36(10):1664-8. doi: 10.1016/j. joen.2010.06.023.

21. Yared G. Canal preparation using only one Ni-Ti rotatory instrument: preliminary observations. Int Endod J. 2008 Apr;41(4):339-44. doi: 10.1111/j.1365-2591.2007.01351.x.

22. Varela-Patiño P, Ibañez-Párraga A, Rivas-Mundiña B, Cantatore G, Otero XL, Martin-Biedma B. Alternating versus continuous rotation: a comparative study of the effect on instrument life. J Endod. 2010 Jan;36(1):157-9. doi: 10.1016/j.joen.2009.09.023.

23. Bürklein S, Benten S, Schäfer E. Quantitative evaluation of apically extruded debris with different single file systems: Reciproc, F360 and One Shape versus Mtwo. Int Endod J. 2014 May;47(5):405-9. doi: 10.1111/iej.12161.

24. Tinaz AC, Alacam T, Uzun O, Maden O, Kayoglu G. The effect of disruption of apical constriction on periapical extrusion. J Endod. 2005 Jul;31(7):533-5. doi: 10.1097/01.don.0000152294.35507.35.

25. Mendonça de Moura JD, Bueno CEDS, Fontana CE, Pelegrine RA. Extrusion of debris from curved root canals instrumented up to different working lengths using different reciprocating systems. J Endod. 2019 Jul;45(7):930-4. doi: 10.1016/j.joen.2019.03.002.

26. Uzunoglu-Özyürek E, Karaaslan H, Türker SA, ÖzçelikB. Influence of size and insertion depth of irrigation needle on debris extrusion and sealer penetration. Restor Dent Endod. 2017 Dec;43(1):e2. doi: 10.5395/rde.2018.43.e2.

27. Tanalp J, Güngör T. Apical extrusion of debris: a literature review of an inherent occurrence during root canal treatment. Int Endod J. 2014 Mar;47(3):211-21. doi: 10.1111/iej.12137. 